\title{
O Reino de Deus a seus destinatários, em uma lgreja pobre para os pobres
}

\section{The Kingdom of God and its recipients, in a poor Church for the poor}

\author{
Antônio Manzatto* \\ Pontifícia Universidade Católica de São Paulo
}

Robert Landgraf**

Professor do Centro Diocesano de Formação Teológica da Diocese de Limeira

Recebido em: 15/06/2020. Aceito em: 12/08/2020.

Resumo: O presente artigo demonstra a centralidade do Reino de Deus na pregação de Jesus analisando os destinatários privilegiados desse anúncio. Ao mesmo tempo, reflete sobre a missão da Igreja no anúncio do Reino. Posto isto, refletimos sobre a Igreja pobre e para os pobres a partir do Concílio Vaticano II, bem como o compromisso dos bispos da América Latina em assumir a opção pelos pobres em Medellín e nas demais Conferências Episcopais do continente. Por fim, estudamos o resgate da centralidade do anúncio do Reino de Deus, bem como seus privilegiados, os pobres, e o resgate de uma Igreja pobre para os pobres na Exortação Apostólica Evangelii Gaudium, do Papa Francisco.

Palavras-chave: Reino. Igreja. Pobre.

Abstract: This paper aims to show how central the Kingdom of God is in Jesus' preaching by analyzing the privileged recipients of this announcement. At the same time, it reflects on the Church's mission of announcing the Kingdom. That said, we reflected on the poor Church for the poor based on the Second Vatican

* Doutor em Teologia (Université Catholique de Louvain, Bélgica, 1993). Mestre em Teologia (Université Catholique de Louvain, Bélgica, 1990). Graduado em Teologia (Pontifícia Faculdade de Teologia Nossa Senhora da Assunção, São Paulo, SP, 1982). Graduado em Filosofia (Faculdades Associadas do Ipiranga, FAI, São Paulo, SP, 1978). E-mail: amanzatto@pucsp.br

** Mestre em Ciências da Religião (Pontifícia Universidade Católica de Campinas, PUC Campinas, Campinas, SP, 2018). Graduado em Teologia (Pontifícia Universidade Católica de Campinas, PUC Campinas, Campinas, SP, 2013). Graduado em Filosofia (Pontifícia Universidade Católica de Campinas, PUC Campinas, Campinas, SP, 2009). E-mail: betolandgraf@yahoo.com.br 
Council as well as on the commitment of Latin American bishops in choosing the side of the poor in Medellin and in other Episcopal Conferences in the continent. Lastly, we studied the retrieval of the central position of the Kingdom of God as well as of its privileged recipients, the poor, and of a poor Church for the poor in Pope Francis' Apostolic Exhortation Evangelii Gaudium.

Keywords: Kingdom. Church. Poor.

\section{Introdução}

A pregação de Jesus concentra-se no anúncio do Reino de Deus. Esse Reino é uma realidade salvífica oferecida pelo Pai à humanidade, desde a criação, e que se manifestou na carne na história de seu Filho feito homem entre os seres humanos na plenitude dos tempos (Gl 4,4). $\mathrm{O}$ Reino anunciado por Jesus é totalmente outro em relação às representações habituais do judaísmo antigo, à expectativa comum, à ordem religiosa estabelecida, aos valores sociorreligiosos tradicionais. Seus beneficiários primeiros e primordiais são os pobres, os não-ricos.

O esquecimento da centralidade do Reino de Deus no anúncio do Nazareno implica na não compreensão de sua profundidade e radicalidade, bem como o esquecimento de suas implicações sociais e eclesiológicas, por isso a importância de procurarmos aprofundar a compreensão dessa centralidade do anúncio do Reino de Deus na pregação de Jesus, bem como os destinatários privilegiados desse anúncio, os destinatários privilegiados desse Reino. A Igreja recebe a missão de anunciar o Reino de Deus e de testemunhá-lo com suas ações, por isso, mais do que nunca, precisa assumir sua identidade de Igreja pobre para os pobres, seguindo o exemplo de seu Mestre, que foi pobre com os pobres.

O Papa João XXIII, com a convocação do Concílio Vaticano II, abre as portas para a concretização desse sonho de uma Igreja que se voltasse para as fontes. Mas é na América Latina, em Medellín, que os bispos assumem a prioridade pastoral que se chamou "opção preferencial pelos pobres", opção assumida em todas as outras conferências episcopais do continente. Com a chegada do Papa Francisco, o Papa Argentino, do "fim do mundo", ocorre um resgate da opção pelos pobres e de uma Igreja pobre para os pobres. Esse projeto pastoral é apresentado à Igreja na Exortação Apostólica Evangelii Gaudium. Um dos objetivos desse trabalho é analisar como a Exortação procura resgatar a centralidade do Reino de Deus, bem como os privilegiados desse Reino e, assim, tornar a Igreja mais fiel e coerente com a missão recebida. 


\section{A centralidade do Reino de Deus na pregação do Nazareno}

Antes de Jesus iniciar sua pregação, João Batista proclamou: "Convertei-vos porque o Reino dos Céus já está próximo” (Mt 3.2). Anunciou um batismo de conversão, uma exigência desse Reino que estava perto. Quando Jesus inicia sua pregação, afirma: "Cumpriu-se o tempo e o Reino de Deus está próximo. Arrependei-vos e crede no Evangelho" (Mc 1,15). Estes versículos do evangelista Marcos podem ser considerados um resumo da missão de Jesus: apontar para a presença do Reino pela ação de Deus. E esta se manifesta na sua pessoa, mensagem e ações. ${ }^{1}$

O Reino apresentado por Jesus como já presente e em íntima conexão com sua pessoa (Lc 4,21; 10,23s; Mt 11,2-6), e não apenas próximo, não é determinado pela ideia de juízo, mas de amor. Nesse reino, a soberania é de um Deus de amor incondicional, misericordioso e libertador. Esse Reino resulta da ação salvífica de Deus e não do esforço humano ou de suas realizações históricas. Entretanto, o ser humano pode pedir sua vinda (Mt 6,10) e buscá-lo (Lc 12,32). ${ }^{2}$

Os evangelhos sinóticos apresentam afirmações sobre o Reino de Deus como uma realidade já presente e também uma realidade futura. Ambas as propostas devem ser respeitadas. O presente inaugura a plenitude salvífica futura, e o futuro penetra e esclarece o presente como tempo oportuno de decisão para alcançá-lo. ${ }^{3}$

Esse Reino pode ser entendido como presença de Deus na humanidade, presença salvífica, ativa, encorajadora, afirmada e acolhida alegremente por todos e que se torna visível na justiça e em relações de paz entre os povos, fazendo desaparecer todo tipo de injustiças e opressões. O Reino e a conversão do ser humano a Deus, criando, assim, um existencial reconciliado consigo mesmo, com o próximo e com a natureza, dando lugar a um mundo pacificado. Reino de Deus é "reino de homens", reino humano, em contraposição aos reinos do mundo que, em Daniel 7, são indicados por símbolos de animais como reinos do poder

\footnotetext{
1 LIBANIO, João B. A redescoberta do Reino na teologia. In: VIRGIL, José Maria (org.). Descer da cruz os pobres: Cristologia da libertação. Comissão teológica internacional. São Paulo: Paulinas, 2007. p. 189-198.

2 MIRANDA, Mario França. A salvação de Jesus Cristo: A doutrina da graça. 2. ed. São Paulo: Loyola, 2009. p. 35.

$3 \quad$ MIRANDA, 2009, p. 35.
} 
do mais forte. Reino de Deus é a eliminação do doloroso contraste ente governantes e governados. ${ }^{4}$

É preciso qualificar o Reino de Deus mais precisamente pela práxis de Jesus relatada pelos Evangelhos sinóticos, pois ela mostra o Reino em realização. Nas ações de Jesus, o Reino vai acontecendo e as pessoas vão sendo libertas e salvas:

João estava na prisão. Quando ouviu falar das obras do Messias, enviou a ele alguns discípulos para lhe perguntarem: "És tu aquele que há de vir, ou devemos esperar outro?" Jesus respondeu: "Voltem e contem a João o que vocês estão ouvindo e vendo: os cegos recuperam a vista, os paraliticos andam, os leprosos são purificados, os surdos ouvem, os mortos ressuscitam e aos pobres é anunciada a Boa Notícia. E feliz aquele que não se escandaliza por causa de mim". (Mt 11,2-6; cf. Lc 7,18-23)

Esse relato da práxis de Jesus mostra que o Evangelho não é só discurso e também não se resume à doutrina. O Evangelho é Boa Notícia, pois resgata a vida, isto é, devolve as condições de vida para quem não tem vida, devolve ânimo e esperança. ${ }^{5}$

Jesus ilustrou em parábolas o que ele entende por Reino de Deus. Através delas, mostra que Deus se posiciona ao lado dos que foram marginalizados pela sociedade, ao lado dos pobres e dos pecadores. A parábola da ovelha perdida expressa esse aspecto (Mt 18,12-14; Lc 15,47): a maneira de agir do pastor tem como objetivo ilustrar a atitude de um Deus que sempre toma a iniciativa de salvar e dar segurança. Outra parábola que enfatiza esse amor misericordioso é a do "filho perdido" (Lc 15,1-32). A maneira de agir do pai com o filho que partiu e gastou tudo provoca indignação no filho mais velho. Mas Jesus lhe ensina que o pecador permanece seu irmão e todos devem partilhar da alegria de Deus pelo seu retorno e conversão.

Na parábola do fariseu e do publicano (Lc 18,10-14), o fariseu piedoso, que de fato segue perfeitamente a Lei e dá graças a Deus por não ser como "aquele pecador", é despedido por Deus. O publicano, que se sente indigno até de comparecer perante Deus, volta para casa

4 SCHILLEBEECKX, Edward. História humana: Revelação de Deus. Trad. João Rezende Costa. São Paulo: Paulus, 1994. (Col. Teologia sistemática, p. 150).

5 FERRARO, Benedito. Reino de Deus. In: Dicionário do Concílio Vaticano II. São Paulo: Paulus, 2015. p. 820, 821. 
"justificado". A parábola dos trabalhadores da décima hora (Mt 20,1-15) mostra que Deus é livre para partilhar seus dons e manifestar seus favores. Nenhuma pessoa por suas boas obras adquire direitos para com Deus, de forma que possa o impedir de manifestar sua bondade para com os que não podem exibir boas obras, ou que, aos olhos dos homens, têm menos “méritos". Essas atitudes de Deus, apresentadas por Jesus nas parábolas, revelam que a bondade radical de Deus apareceu em meio à humanidade e visam eliminar as imagens de um Deus conformado com a situação de opressão em que vivia o povo de sua época. ${ }^{6}$

Com isso, Jesus ensina que as normas para a práxis do Reino não se condicionam às regras do jogo social: trata-se de um agir alternativo. É importante salientar que Jesus não defende pessoas imorais e anarquistas, mas se coloca ao seu lado oferecendo outra possibilidade existencial. Desmascara as intenções dos zelosos de Deus da justiça e tira-lhes até o que têm: ele sabe dos efeitos perversos e desumanos da virtude, tal qual o manifesta o irmão mais velho do filho perdido ( $\mathrm{Lc}$ 15,11-32) que, na sua autossuficiência, não se alegra com o arrependimento do irmão mais novo. Jesus se posiciona contra os guardiões das regras do jogo social; condena a justiça rigorosa que muitas vezes pode envolver excomunhão de pessoas que já são publicamente rejeitadas. A vinda do Reino de Deus visa resgatar a esperança aos que, vistos pelo prisma social e humano e segundo as regras do jogo social, carecem de toda esperança. ${ }^{7}$

Jesus age da forma como Deus age; sendo assim, reside nele a pretensão de que o próprio Deus está presente no seu agir e falar. Dessa maneira, agir da mesma forma que Jesus constitui a práxis do reino de Deus, evidenciando, portanto, a um só tempo, o que seja o reino de Deus: a salvação para os homens. ${ }^{8}$

Jesus desloca o acento do Reino para a figura de Javé, como Pai (Abba), seu e nosso, que age nas próprias obras de Jesus, na linguagem de João $(10.37,38)$. Nele acontece o Reino. Estabelece-se, então, uma segunda relação entre Jesus e o Reino, que lentamente conduzirá a comunidade a identificá-lo com o Reino. ${ }^{9}$

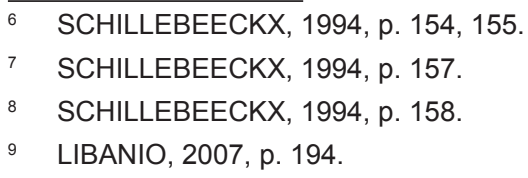


À primeira vista, o enfoque no Jesus histórico, bem como na sua pregação do Reino, parece desconhecer a realidade absoluta que o próprio Jesus significa e é. A Teologia da Libertação coloca ênfase na dimensão da historicidade de Jesus e da centralidade no Reino em sua vida, questionando certa cristologia que começa a pensar Jesus a partir da divindade. Repete-se, hoje, a tensão que nos inícios houve entre a cristologia antioquena, com acento sobre a humanidade, e a cristologia alexandrina, com a tônica sobre a divindade. Essa tensão é superada quando não há negação da relação de exterioridade e dependência de Jesus no seu caráter histórico, em face do Reino, mas avançando a reflexão. No primeiro momento, a inferioridade de Jesus com respeito ao Reino manifesta o limite de sua consciência humana histórica. Permanece dado na revelação. ${ }^{10}$

No entanto, vale o contrário. Na sua última raiz, Jesus constitui-se pelo relacionamento com o Pai (Abba), na repetida insistência do evangelho de João. O termo relação é tão forte que a teologia trinitária o escolheu para definir as pessoas divinas. Tem um sentido diferente do que usamos para relações acidentais da vida. Por experiência, percebemos a diferença nas relações que estabelecemos. Vão desde aquelas bem superficiais, com coisas que nos cercam, passando pelas que nos vinculam a compromissos e pessoas, até aquela com Deus criador e salvador, que nos constitui como ser. É tão válido dizer que o Reino de Deus e o Deus do Reino são maiores que Jesus quanto dizer que ele se define, constitutivamente, por eles numa igualdade radical. Jesus disse que faríamos coisas maiores que ele (Jo14.12), mas sabemos que não fazemos sem a presença dele. ${ }^{11}$

Continuam válidas, portanto, as duas afirmações em formas antitéticas, isto é, provocativas entre si. Jesus histórico prega, anuncia, atualiza o Reino de Deus, que ultrapassa a historicidade de sua vida. O Reino faz-se presente em todos os tempos e espaços, além de tudo o que ele fez e disse. A fé cristã posterior, iluminada pela ressurreição de Jesus, interpretando tudo a partir do Cristo glorificado, identifica-o com o Reino de tal maneira que, onde houver a mínima presença do Reino, aí estará também o Senhor presente. ${ }^{12}$

\footnotetext{
$10 \quad$ LIBANIO, 2007, p. 194

11 LIBANIO, 2007, p. 194.

12 LIBANIO, 2007, p. 195.
} 


\section{O Reino de Deus e os pobres, destinatários privilegiados a partir das bem-aventuranças}

Ao anunciar o Reino de Deus, Jesus trazia esperança, sobretudo aos pobres. Esse Reino é caracterizado como uma realidade paradoxal, pois é totalmente avesso às representações habituais do judaísmo antigo, à expectativa comum, à ordem religiosa estabelecida, aos valores sociorreligiosos tradicionais. Seus destinatários primeiros e privilegiados são os pobres, os "pecadores", as crianças. Quando se perde essa característica do anúncio da vinda do Reino de Deus anunciado por Jesus, não é possível compreendê-lo em toda sua profundidade e radicalidade.

A centralidade dos pobres no Reino é uma evidência no Novo Testamento. O evangelista Lucas formulou-a de maneira taxativa, sem adjetivação: "felizes vós que sois pobres, porque o Reino dos céus vos pertence!" (Lc 6,20). E, se não bastasse, virou a bem-aventurança em mal aventurança em relação aos ricos: "Mas ai de vós, que sois ricos, porque já tendes o vosso consolo!" (Lc 6,24). Lucas fala diretamente dos pobres em três condições: de pobreza, de fome e de lágrimas. Na raiz das bem-aventuranças, está a natureza do Reino: a disposição de Deus de exercer seu reinado em favor dos mais deserdados deste mundo. Estamos diante do privilégio do pobre por ser pobre, cujo último fundamento não está nele, mas no amor de Deus com respeito a ele. Mistério da ternura divina, que prefere o pobre na sua condição de pobreza para aí mostrar seu Reinado. ${ }^{13}$

A densidade cristológica das bem-aventuranças permite compreender o que significou, para os pobres, o início do ministério de Jesus na Galileia. Ela não deve obnubilar, contudo, a densidade teológica das mesmas bem-aventuranças e, em geral, da proclamação do Reino de Deus. Com efeito, a missão de Jesus é toda ela voltada para a vinda do Reino de Deus. O decisivo é a realidade da mensagem. O mensageiro quase que se apaga detrás dela. E a mensagem que o mensageiro anuncia é o privilégio dos pobres no Reino que vem. A razão de ser desta predileção não está nas qualidades morais ou religiosas dos pobres, mas na opressão e marginalização dos pobres, ou seja, é a situação de sofrimento dos pobres e dos infelizes, e não suas condições interiores, o que atrai sobre eles a benevolência divina. ${ }^{14}$

13 LIBANIO, 2007, p. 196.

14 BARREIRO, Álvaro. Os pobres e o Reino: do evangelho a João Paulo II. São Paulo: Loyola, 1983. p. 87. 
A bem-aventurança dos pobres não pode ser espiritualizada, porque ela continua sendo dirigida aos pobres reais, que sofrem toda sorte de privações, aqueles que objetivamente estão às margens da sociedade civil e religiosa do tempo de Jesus. São pobres em sentido sociológico: pessoas sem propriedade, que vivem na pobreza concreta. Os destinatários das bem-aventuranças, segundo Lucas, são os cristãos perseguidos e que, por isso mesmo, vivem em condições penosas, são de fato pobres. $\mathrm{Na}$ atualidade, poderíamos afirmar que são "pessoas empobrecidas", porque são perseguidos, despojados e marginalizados, são feitos pobres. ${ }^{15}$

O grande perigo é realizar uma leitura "romantizada" das bem-aventuranças, o que leva ao erro de não perceber o escândalo e alterações dos valores encontrados nelas. Jesus proclama bem-aventurados e felizes aqueles que para a sociedade de sua época e de todas as épocas são considerados desgraçados e infelizes: os pobres, os que têm fome e sede, os que choram, os perseguidos e caluniados, os afligidos. Os que são apenas números em estatísticas. Deles é o Reino de Deus. Esse é o motivo da sorte e da felicidade. Por isso o "Evangelho" é "novidade". Jesus revela que Deus está onde menos se espera, sobretudo onde menos o esperam os establishments religioso-culturais que na história pretenderam se converter em mediadores exclusivos com o único e verdadeiro Deus. ${ }^{16}$

As bem-aventuranças não admitem moralizações fácies; é preciso acolher, aceitar e transmitir seu verdadeiro significado: que a felicidade dos bem-aventurados não está na pobreza, na fome, na dor ou na perseguição, mas está na presença de Deus junto a eles. O que significa dizer que sua sorte não é o castigo por seus pecados nem predestinação fatal divina, mas consequência de causas histórico-sociais que podem ser revertidas, pois dependem da ação de outros seres humanos. Assim, Deus deixa de ocupar o lugar de garantidor da ordem vigente. ${ }^{17}$

Escolhendo os pobres para serem os herdeiros do reino, Deus põe em ação uma nova ordem de valores na qual os pobres são os privilegiados. Assim, as bem-aventuranças significam na boca Jesus a proclamação do grande "não" de Deus à ordem de valores morais, religiosos, sociais,

15 BARREIRO, 1983, p. 95.

16 CABESTRERO, Teófilo. Primazia dos pobres na missão de Jesus e da Igreja. Influência do Concílio Vaticano II no magistério Episcopal de Medellín, Puebla e Santo Domingo. In: VIRGIL, José Maria (org.). Descer da cruz os pobres: Cristologia da libertação. Comissão teológica internacional. São Paulo: Paulinas, 2007. p. 49-57.

17 CABESTRERO, 2007. p. 57. 
econômicos e jurídicos vigentes, geradores de exclusão, pobreza e sofrimento. Deste modo, Jesus torna manifesto, de maneira contundente, de que lado Deus está. As bem-aventuranças revelam quem é o Deus do Reino que Jesus vem anunciar. Dizem-nos que é Deus e qual é o seu Reino, fala-nos de Deus como defensor, protetor e libertador dos pobres. A eles é destinada, prioritariamente, a felicidade do Reino, que é Reino de Deus. ${ }^{18}$

\section{A Igreja e a missão de anunciar o Reino de Deus}

A missão de Jesus prolonga-se na de seus próprios enviados, os Doze, os quais, por essa razão, são chamados apóstolos. Eles são enviados para pregar o Evangelho e curar os enfermos ( $\operatorname{Lc} 9,1 \mathrm{~s})$, o que é missão pessoal de Jesus. São os operários enviados para a messe pelo Mestre (Mt 9,38; cf. Jo 4,28). Estes enviados terão a mesma sorte: "Quem vos ouve a mim ouve, e quem vos rejeita a mim rejeita; mas quem me rejeita, rejeita aquele que me enviou" (Lc 10,16). A missão dos apóstolos, com efeito, está estreitamente enraizada na missão de Jesus: "como o Pai me enviou, assim também eu vos envio" (Jo 20,21). Esta expressão esclarece o sentido profundo da missão final dos Doze: "Ide...". Por isso eles proclamam o evangelho (Mc 16,14), de todas as nações fazem discípulos (Mt 28,19), levando o seu testemunho até as extremidades da terra (At 1,8). ${ }^{19}$

Os apóstolos cumprem essa missão com a força do Espírito Santo, "O Paráclito", "o Espírito Santo que o Pai enviará em meu nome, vos ensinará todas as coisas" (Jo 14,26). Assim, o Espírito Santo recebido no dia de Pentecostes (At 2,1-36) tornou-os testemunhas em Jerusalém, na Judeia, na Samaria e até os confins da terra (At 1,8). É esse contexto de Pentecostes como manifestação inicial dessa missão do Espírito que durará por todo o tempo da Igreja. A missão é, pois, uma tarefa que diz respeito a toda a Igreja em virtude do seu caráter essencial, ou seja, enquanto ela é comunidade de salvação de Cristo, e em virtude de seu lugar na história da salvação, estando situada entre a Ascensão e a Parusia final. O corolário disso é afirmar que a catolicidade da Igreja se expressa

18 GUTIÉRRES, Gustavo. A força histórica dos pobres. Trad. Álvaro Cunha. Rio de Janeiro: Vozes. 1981. p. 133-134.

19 PIÉ NINOT, Salvador. Introdução à Eclesiologia. Trad. João Peixoto Netto. São Paulo: Loyola, 1998. p. 99. 
quando seus membros colocam em prática esse mandato de Jesus. ${ }^{20} \mathrm{O}$ documento Ad Gentes explica que a Igreja está no caminho iniciado por Jesus de Nazaré e continuado pelos apóstolos:

A Igreja enviada por Deus a todas as gentes para ser "sacramento universal de Salvação, por íntima exigência da própria catolicidade, obedecendo a um mandato do seu fundador procura incansavelmente anunciar o Evangelho a todos os homens". Já os próprios apóstolos em que a Igreja se alicerça, seguindo o exemplo de Cristo, "pregaram a palavra de verdade e geraram as Igrejas". Aos seus sucessores compete perpetuar esta obra, para que "a Palavra de Deus se propague rapidamente e seja glorificada" (2Ts 3.1), e o reino de Deus seja pregado e estabelecido em toda terra. ${ }^{21}$

Respeitando os diferentes contextos históricos e sociais, a Igreja recebe a mesma missão de Jesus de Nazaré, ou seja, anunciar a Boa Nova do Reino de Deus (Lc 4,43). O Concílio Vaticano II ensina que esta missão deve ser realizada com o mesmo Espírito de caridade do Nazareno:

E assim como Cristo percorria todas as cidades e aldeias, curando todas as doenças e todas as enfermidades, proclamando o advento do Reino de Deus, do mesmo modo a Igreja, por meio de filhos estabelece relações com os homens de qualquer condição, de modo especial os pobres e aflitos, e de bom grado por eles gasta as forças. Participa de suas alegrias e dores, conhece as suas aspirações e os problemas da sua vida e sofre com eles nas ansiedades da morte. Àqueles que buscam a paz deseja responder com diálogo fraterno trazendo-lhes paz e a luz do Evangelho. ${ }^{22}$

A Igreja é formada por um povo messiânico e recebe o mandamento novo de amar como Jesus nos amou (cf. Jo 13,34), tendo como objetivo a construção do Reino de Deus no hoje da história, iniciado já na Terra pelo próprio Deus, revelado em Jesus de Nazaré, e que deve ser ininterruptamente desenvolvido até que, no fim dos tempos, seja por ele completado quando Cristo, nossa vida e salvação, aparecerá (cf. $\mathrm{Cl}$ 3,4 ), “e a própria criatura será libertada do cativeiro da corrupção para

20 PIÉ NINOT, 1998, p. 100.

21 COSTA, Lourenço (org.). Documentos do Concílio Ecumênico Vaticano II. Ad Gentes (AG). Trad. Tipografia Poliglota Vaticana. São Paulo: Paulus, 1997. (Col. Documentos da Igreja, n. 11).

22 AG, 1997, n. 12. 
a gloriosa liberdade dos filhos de Deus" (Rm 8,21). Destarte, esse povo messiânico, embora não contemple no tempo presente todos os homens e por vezes se manifeste como pequeno rebanho, é, todavia, para todo o gênero humano, princípio de unidade, esperança e salvação. Constituído por Cristo para a comunhão de vida, caridade e verdade, é por ele ainda assumido como instrumento de redenção de todos e é enviado ao mundo inteiro como luz do mundo e sal terra (Mt 5,13-16) (23 $24^{24}$

O Concílio Vaticano II apresenta Maria como exemplo a ser seguido pela Igreja, pois ela, no Magnificat (Lc 1,46-56) canta a centralidade dos pobres no Reino de Deus e se coloca como discípula deste reino. No Cântico, fica manifesta a graça que o anúncio do Reino traz para toda a humanidade, de tal modo que a caridade cristã deverá se estender a todos os seres humanos sem discriminação de raça, de condição social ou religião e sem esperar qualquer benefício, pois o anúncio deve seguir o princípio da gratuidade. ${ }^{25}$

\section{A Igreja Samaritana: pobre para os pobres}

Por ocasião do Concílio Vaticano II, houve intensa reflexão em torno do tema: "Igreja pobre", "Igreja dos pobres", "evangelização dos pobres", relação dos pobres com o mistério de Cristo e da Igreja. ${ }^{26}$

Exatamente um mês antes da abertura do Concílio, na sua radiomensagem de 11 de setembro de 1962, João XXIII declarava: "Em face dos países subdesenvolvidos, a Igreja apresenta-se tal qual é e quer ser, como a Igreja de todos, e particularmente a Igreja dos pobres". Maior ressonância dentro e fora do Concílio sobre a "Igreja dos pobres" foi a intervenção do cardeal arcebispo de Bolonha (Itália), Giácomo Lercaro, quando o Concílio ainda buscava seu rumo no final de sua agitada primeira sessão, exatamente no dia 6 de dezembro. Assim, Lercaro asseverou:

A intenção de minhas palavras é que elas nos façam mais atentos para o aspecto deste mistério de Cristo na Igreja, aspecto não só perene e essencial, mas também de máxima atualidade histórica. Ora, o mistério

\footnotetext{
23 DOCUMENTOS do Concílio Ecumênico Vaticano II. Lumen Gentium (LG). Trad. Tipografia Poliglota Vaticana. São Paulo: Paulus, 1997. (Col. Documentos da Igreja, n. 9).

24 FERRARO, 2015. p. 822.

25 FERRARO, 2015. p. 822.

26 BARREIRO, 1983, p. 135.
} 
de Cristo na Igreja sempre foi e é, mas hoje o é principalmente, o mistério de Cristo nos pobres; uma vez que a Igreja, como diz o Santo Padre João XXIII, é a Igreja de todos, mas especialmente a "Igreja dos pobres". Não responderemos satisfatoriamente ao nosso múnus e não acolheremos com espírito aberto o desígnio (consilium) de Deus e as expectativas dos homens se não fizermos do mistério de Cristo nos pobres e da evangelização dos pobres o centro e a alma de toda a obra doutrinal e legislativa deste Concílio. Não daremos satisfação às exigências mais autênticas e mais profundas de nossa época, incluída nossa máxima esperança na unidade de todos os cristãos, se abandonarmos o tema da evangelização dos pobres como um a mais dentro dos muitos temas do Concílio. Não se trata, com efeito de um tema qualquer; trata-se de uma maneira, do tema essencial do nosso Concílio. De fato, se o tema deste Concílio - como aqui foi dito várias vezes - é a Igreja na [na busca da] sua conformidade à verdade eterna do Evangelho e ao mesmo tempo na [busca da] adequação às situações de nossa época, podemos afirmar que o tema deste Concílio é a Igreja, principalmente enquanto "'Igreja dos pobres". ${ }^{27}$

Percebe-se na Fala do Cardeal Lercaro o desejo de que o Concílio tenha como centro articulador de todas as temáticas o "Mistério de Cristo nos pobres da terra" e o "Mistério da Igreja mãe dos pobres". Também cobrou "prioridade para formular a doutrina evangélica sobre a eminente dignidade dos pobres no Reino de Deus e na Igreja" e pediu que o Concílio estabelecesse "o primado eclesial da evangelização dos pobres". ${ }^{28}$

Apesar da fala do Cardeal Lercaro, o Concílio não fez da "Igreja dos Pobres" o tema central de sua reflexão. O tema da "Pobreza da Igreja" era para Lercaro uma pedra de toque e deveria ser o centro nevrálgico, como um princípio unificador e vivificador de toda a eclesiologia do Concílio. $^{29}$

A discussão Eclesiológica presente na Lumem Gentium indica o caminho para uma Igreja chamada a seguir Jesus e sua pobreza:

Do mesmo modo que Jesus Cristo consumou a sua obra da redenção na pobreza e na perseguição, assim também, a Igreja é chamada a seguir o

27 BARREIRO, 1983, p. 135-136.

28 CABESTRERO, 2007. p. 49-50.

29 SOUZA, Ney de. Pobreza da Igreja: História e teologia do documento 14 da Conferência de Medelín. Caminhos, Goiânia, v. 17, n. 2, maio-ago. 2019, p. 527-740. 
mesmo caminho para poder comunicar aos homens os frutos da Salvação. Cristo Jesus, tendo "condição divina...esvaziou-se a si mesmo e assumiu a condição de servo" (Fl 2,6-7) e por causa de nós "ele que era rico, fez-se pobre" (2Co 8.9): assim a Igreja, se bem que precise de recursos humanos para cumprir a sua missão, não foi constituída para buscar glórias terrenas, mas para dar a conhecer, também com seu exemplo, a humildade e a abnegação. Cristo foi enviado pelo Pai "para evangelizar os pobres... "a proclamar e remissão aos presos" (Lc 4,18), "a procurar e salvar o que estava perdido" (Lc 19,10): de modo semelhante, a Igreja envolve em seus cuidados amorosos todos os angustiados pela fraqueza humana, e mais, reconhece nos pobres e nos que sofrem, a imagem de seu Fundador, pobre e sofredor, esforça-se por aliviar-lhes a indigência $e$, neles, quer servir a Cristo. ${ }^{30}$

A Constituição Gaudium et Spes (n. 8) e o decreto Ad Gentes (n. 5) expandem para as comunidades Cristãs e para toda a Igreja o seguimento da pobreza. Assim, o caminho da pobreza é apresentado a partir dos documentos do Concílio Vaticano II e a sua leitura das Escrituras, na dimensão do desapego afetivo, da partilha e da sobriedade e como ideal econômico. ${ }^{31}$ A partir desse novo olhar hermenêutico, que vê no pobre a pessoa de Jesus e nos valores do mundo os antivalores do Reino, os padres conciliares possibilitaram que cada realidade, cada continente, cada Conferência Episcopal, pudesse em seu contexto socio eclesial refletir estratégias para uma evangelização compromissada com a transformação social. ${ }^{32}$

O Episcopado latino-americano, com o desejo de colocar em prática as decisões do Vaticano II, realizou, três anos após, a segunda Conferência Episcopal latino-americana na cidade de Medellín (1968), com o tema: A Igreja na atual transformação da América Latina à luz do Concílio.

Reunidos em Medellín, os bispos reconheceram que a Igreja não poderia ficar indiferente às injustiças sociais presentes no continente Latino Americano. O documento conclusivo da conferência está carregado de profunda solidariedade para com os pobres e sofredores. Nele,

30 LG, n. 8.

31 SILVA, Rafael Rodrigues da. Pobreza Evangélica. In: Dicionário do Concílio Vaticano II. São Paulo: Paulus, 2015. p. 745-746.

32 LOURENÇO, Vitor Hugo. A "opção preferencial pelos pobres" como chave hermenêutica da Exortação Apostólica Evangelii Gaudim. Revista de Cultura Teológica. São Paulo, ano XXV, n. 89, jan.-jun. 2017, p. 380-407. 
os bispos assumem que a Igreja da América Latina esteve letárgica e, por isso, sentem-se evangelicamente obrigados, como pastores, a dar voz àqueles que não a têm: "A pobreza de tantos irmãos clama por justiça, solidariedade, testemunho, compromisso, esforço e superação para o cumprimento pleno da missão salvífica confiada por Cristo". ${ }^{33}$

Medellín convoca a Igreja a se assumir também como pobre, fazendo-se pobre com os pobres. Surgem, nesse período, muitas comunidades religiosas na periferia com o objetivo de se fazerem pobres com os pobres, de estabelecer um diálogo profundo e eficaz com os que são vítimas das consequências da crueldade das crises do capitalismo. Deixa transparecer uma Igreja que não mais se conforma em implantar um modelo europeu-colonial. Antes, ela quer oportunizar uma experiência de Jesus de Nazaré que se dá historicamente. ${ }^{34}$

Em 1979, os bispos da América Latina reúnem-se em Puebla para a terceira Conferência do Episcopado Latino Americano. Esta conferência torna-se referência na opção pelos pobres. Passa a utilizar a palavra "pobre" no sentido de anawin, que significa o curvado, o oprimido. O termo tem, na Bíblia, uma conotação político-social. Designa o escravo, o estrangeiro, o perseguido, o cativo. Não se trata simplesmente do necessitado, mas do oprimido, do explorado. Não refere apenas à pessoa, mas à classe social explorada, à raça marginalizada, ao grupo oprimido. ${ }^{35}$

O documento conclusivo de Puebla, nos parágrafos 31 a 49, especifica quem são os pobres da América Latina. Indígenas e afro-americanos, camponeses sem-terra, operários, desempregados e subempregados, marginalizados e aglomerados urbanos, jovens frustrados socialmente e desorientados, crianças golpeadas pela pobreza, menores abandonados e carentes, a mulher, migrantes e prostitutas. Trata-se não da pobreza evangélica, mas da pobreza antievangélica, que é sinônimo de exploração de opressão, de desumanidade. Trata-se da pobreza de dimensão sociopolítica, que significa uma pobreza de dimensão generalizada e estrutural. ${ }^{36} \mathrm{O}$ documento afirma:

33 LOURENÇO, 2017, p. 391.

34 BOAS, Alex; MARCHINI, Welder Lancieri. Medellín como recepção conciliar. In: SOUZA, Ney de; SBARDELOTTI, Emerson. Medellín: Memória, profetismo e esperança na América Latina. Petrópolis: Vozes, 2018. p. 114.

35 LOURENÇO, 2017, p. 391.

36 LOURENÇO, 2017, p. 391. 
A opção preferencial pelos pobres tem como objetivo o anúncio de Cristo Salvador, que os iluminará sobre sua dignidade, os ajudará em seus esforços de libertação de todas as suas carências e os levará à comunhão com o Pai e os irmãos, mediante vivência da pobreza evangélica. Jesus Cristo veio para compartilhar nossa condição humana com seus sofrimentos, suas dificuldades, sua morte. Antes de transformar a existência cotidiana, ele soube falar ao coração dos pobres, libertá-los do pecado, abrir seus olhos para um horizonte de Luz e enchê-los de alegria e esperança. Hoje, Jesus Cristo faz o mesmo. Está presente em vossas Igrejas, em vossas famílias, em vossos corações. ${ }^{37}$

Por esses pobres opta, decidida e inequivocamente, a Igreja na América Latina. Esta opção, como é afirmada expressamente várias vezes, não é exclusiva. Mas a afirmação de não excludência não pode ser entendida e praticada de tal maneira que acabe destruindo de fato a "opção preferencial pelos pobres"; que acabe, paradoxalmente, excluindo justamente os pobres, que acabe, na prática, optando preferencialmente pelos ricos. O texto conclusivo assinado pelos bispos é enfático em afirmar que a opção pelos pobres tem que ser "preferencial", especial. E repete insistentemente as conhecidas razões teológicas e cristológicas, evangélicas, deste privilégio. ${ }^{38}$

Nos passos de Medellín e Puebla, a Conferência de São Domingos (1992), reafirmou a "opção preferencial pelos pobres". Contra todo tipo de ideologia, o documento afirma que esta opção está alicerçada na Palavra de Deus e não apenas em parâmetros retirados das ciências humanas ou fruto da rivalidade entre grupos divergentes entre si, que, não raras vezes, de maneira reducionista, conceituam os pobres em categorias sociopolíticas econômicas abstratas. ${ }^{39}$

Na quinta Conferência do Episcopado Latino Americano realizada no Brasil, na cidade de Aparecida (2007), foi retomado o tema da preocupação com os pobres e excluídos do continente. $\mathrm{O}$ documento chama a atenção para o fato de que a globalização fez aparecer novos rostos de pobres e elenca o rosto concreto dos novos excluídos, a quem a pastoral da Igreja deve dar especial atenção. O documento (n. 399) declara assumir "com nova força essa opção preferencial pelos pobres, reforçando sua

37 EVANGELIZAÇÃO no presente e no futuro da América Latina. Conclusões da Conferência de Puebla: texto oficial. (DP). 3. ed. São Paulo: Paulinas, n. 1153. 
fundamentação cristológica e a profunda e íntima identificação do rosto de Jesus com o rosto do pobre". ${ }^{40}$ Segundo o Documento de Aparecida, a opção preferencial pelos pobres é uma das características que marca a fisionomia da Igreja no Continente Latino Americano e afirma que "a opção preferencial pelos pobres está implícita na fé cristológica naquele Deus que se fez pobre por nós, para nos enriquecer com sua pobreza". ${ }^{41}$

No continente Latino Americano, marcado por inúmeras desigualdades e injustiças sociais, a Igreja, naquilo que compõe sua tradição libertadora, lutou e continua a lutar, apesar das resistências, para colocar em prática a renovação proposta pelo Concílio Vaticano II. Por isso, cabe a todos os batizados, discípulos-missionários, seguidores do Ressuscitado, voltar constantemente a Jesus de Nazaré para dar continuidade à sua prática, colocando-se ao lado dos pobres e lutando contra todo tipo de injustiça.

É deste continente Latino Americano que vem o Papa Francisco, eleito em 13 de março de 2013. Ele carrega consigo a experiência eclesial viva e dinâmica, própria da Igreja Latina Americana com suas lutas, comprometida com a justiça e com a defesa dos empobrecidos.

O projeto de "uma Igreja pobre e para os pobres" está no centro das preocupações pastorais de Francisco, como indica a Exortação apostólica Evangelii Gaudium, que trata do anúncio do Evangelho no mundo atual. Nesta Exortação, o Papa universalizou a toda Igreja o espírito do Documento de Aparecida, ao qual Francisco deu sua colaboração. ${ }^{42}$

Na compreensão hermenêutica de Francisco, exposta de modo explícito, "a opção pelos pobres é mais uma categoria teológica que cultural, sociológica, política ou filosófica". ${ }^{43}$ E "no coração de Deus, ocupam lugar preferencial os pobres, tanto que ele mesmo Se fez pobre" $(2 \operatorname{Cor} 8,9)^{44}$ e "esta preferência divina" tem consequência na vida de fé

40 BOMBONATTO, Vera Ivanise. Jesus e a opção pelos pobres. In: OLIVEIRA, Pedro A. R. de (org.). Opção pelos pobres no século XXI. São Paulo: Paulinas, 2011. p.139.

41 CONSELHO Episcopal Latino Americano. Documento de Aparecida (DAp). Texto Conclusivo da V Conferência Geral do Episcopado Latino Americano e do Caribe. 7. ed. São Paulo: Paulus. 2008. n. 391-392.

42 LOURENÇO, 2017, p. 399.

43 PAPA FRANCISCO. Evangelii Gaudium, a alegria do Evangelho: sobre o anúncio do Evangelho no mundo atual. (EG). São Paulo: Paulus, 2013. n. 198.

44 EG, n. 198. 
de todos os cristãos, chamados a possuir "os mesmos sentimentos que estão em Cristo Jesus" (F1 2,5). ${ }^{45}$

O Papa percorre vários textos da Escritura e da Reflexão da Igreja ao longo dos séculos para mostrar que "todo o caminho da nossa redenção está assinalado pelos pobres" ${ }^{46}$, ensinando que a partir do coração do Evangelho é possível reconhecer a conexão íntima que existe entre evangelização e promoção humana, que se deve manifestar e desenvolver em toda a ação evangelizadora da Igreja ${ }^{47}$, cujos pobres são destinatários privilegiados desta ação:

Não devem subsistir dúvidas nem explicações que debilitem esta mensagem claríssima. Hoje e sempre, "os pobres são os destinatários privilegiados do Evangelho", e a evangelização dirigida gratuitamente a eles é sinal do Reino que Jesus veio trazer. Há que afirmar sem rodeio que existe um vínculo indissolúvel entre nossa fé e os pobres. ${ }^{48}$

Por isso, no processo de evangelização, ficar "surdo" ao clamor dos pobres, "coloca-nos fora da vontade do Pai e do seu projeto; a falta de solidariedade, nas suas necessidades, influi diretamente sobre nossa relação com Deus". ${ }^{49}$ E nisso não há dúvidas nem meias palavras. A opção pelos pobres é inerente ao coração do Evangelho, do reinado de Deus e, por isso, é constitutiva da fé cristã. ${ }^{50} \mathrm{O}$ papa se posiciona contra pensamentos teológicos e ideológicos de relativizar e enfraquecer na Igreja a opção pelos pobres:

É uma mensagem tão clara, tão direta, tão simples e eloquente que nenhuma hermenêutica eclesial tem o direito de relativizá-la. A reflexão da Igreja sobre estes textos não deveria ofuscar nem enfraquecer seu sentido exortativo, mas antes ajudar a assumi-lo com coragem e ardor. Para que complicar o que é tão simples? As elaborações conceituais hão de favorecer o contato com a realidade que pretendem explicar, $e$ não afastar-nos dela. Isso vale, sobretudo para as exortações biblicas

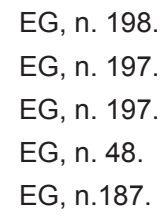

50 AQUINO JUNIOR, Francisco de. Uma Igreja pobre e para os pobres: abordagem teológico-pastoral. Revista Pistis \& Práxis, teologia e Pastoral. Curitiba, v. 8, n. 3, set.-dez. 2016, p. 644. 
que convidam, com tanta determinação, ao amor fraterno, ao serviço humilde e generoso, à justiça, à misericórdia para com o pobre. ${ }^{51}$

A opção pelos pobres continua na atualidade sendo o "critério-chave de autenticidade" nas ações da Igreja. Se há "um sinal que nunca deve faltar" nos membros da Igreja, é a "opção pelos últimos, por aqueles que a sociedade descarta e lança fora". ${ }^{52}$

Francisco entende que é preciso agir, incidir com eficácia nas situações de pobreza e sofrimento, mas sabe que não há uma receita pronta. Por isso, é preciso refletir a partir dos desafios de cada contexto e das possibilidades de ação o que exige muita lucidez, criatividade e ousadia. ${ }^{53} \mathrm{O}$ pontífice apresenta algumas diretrizes para dinamizar a opção pelos pobres na Igreja, consequentemente fazendo dela uma Igreja samaritana e pobre:1)é necessário se envolver "com a cooperação para resolver as causas estruturais da pobreza e promover o desenvolvimento integral dos pobres" "54; 2) a proximidade física dos pobres e o esforço por socorrê-los em suas necessidades imediatas pois é "unicamente a partir dessa proximidade real e cordial que poderá haver libertação" 55 ; 3) os pobres em sua maioria possuem uma abertura à fé, por isso necessitam do cuidado espiritual, ou seja, a solicitude religiosa privilegiada e prioritária ${ }^{56}$; 4) promover o fortalecimento de uma cultura da solidariedade com o objetivo de criar uma mentalidade que pense em termos de comunidade ${ }^{57}$; e 5) buscar o enfrentamento das causas estruturais da pobreza e da injustiça no mundo, pois a Igreja não pode nem deve ficar fora da luta pela justiça. ${ }^{58}$

A "Igreja pobre para os pobres" desejada pelo Papa Francisco é, consequentemente, um princípio norteador que orienta e qualifica, no sentido evangélico, a escolha da pobreza e o serviço aos pobres, continuando, assim, a missão caritativa da Igreja que em séculos de história foi instrumento de libertação, inclusão e promoção dos po-

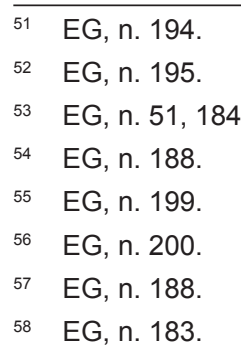


bres, tendo a perspectiva da liberdade e do amor de Cristo. Ele não só oferece uma solidariedade concreta, estável e generosa, mas está efetiva e afetivamente encarregado também para afirmar a dignidade da pessoa, da busca da justiça, a fim de construir uma civilização do amor e da solidariedade. ${ }^{59}$

Na visão de Francisco, evangelizar possui uma dimensão social, pois ela torna o Reino de Deus presente em um mundo no qual os privilegiados são os pobres, ou seja, aqueles que para o sistema capitalista neoliberal são descartáveis. É preciso reforçar que a opção pelos pobres não se resume a uma questão cultural, sociológica ou política, como muitos membros conservadores da Igreja defendem, querendo com isso desviar o foco da mensagem cristã e assim permanecerem na zona de conforto. A opção pelos pobres, inspirada nas ações do Nazareno é, antes de tudo, uma opção evangélica, bíblica e teológica. Os pobres constituem um lugar teológico onde compreendemos o cerne da mensagem Cristã, onde somos evangelizados. ${ }^{60}$

Nestes tempos em que a pandemia do Covid-19 assola o mundo e escancara ainda mais as diferenças sociais, o Papa Francisco com sensibilidade para com os empobrecidos solicita ao Dicastério para o Serviço do Desenvolvimento Humano Integral a formação, em colaboração com outros dicastérios da Cúria Romana, de uma comissão especial de enfrentamento do Covid-19, para exprimir a solicitude e o amor da Igreja pela família humana diante da dura realidade da pandemia, principalmente mediante a análise e a reflexão dos desafios socioeconômicos e culturais do futuro e a proposta de diretrizes para enfrentá-lo. Outro gesto do pontífice ocorreu no dia 31 de maio de 2020, dia de Pentecostes, na oração Regina Coeli, na qual, de maneira profética, afirma que as pessoas são mais importantes do que a economia: "cuidar das pessoas, não poupar (dinheiro) para ajudar a economia (é importante), cuidar das pessoas, que são mais importantes que a economia, nós, pessoas, somos templos do Espírito Santo, a economia não", afirmou Francisco, denunciando, assim, muitos líderes políticos que fecharam os olhos às dores do povo, em especial dos mais vulneráveis em função da economia. Entretanto, Francisco não fica apenas em palavras e cria um fundo para as áreas de missão afetadas pelo vírus, chamando a toda a Igreja para ajudar por meio das Pontifícias Obras

59 LOURENÇO, 2017, p. 402.

60 EG, n. 176, 195, 198. 
Missionárias de cada país, que são o canal oficial de apoio ao Papa para mais de 1.110 dioceses, especialmente na Ásia, África, Oceania e parte da região Amazônica. Os pobres do Brasil não ficaram fora desse olhar paternal do Papa: uma das contribuições foi o envio de 10 mil reais para compra de cestas básicas a uma das regiões mais afetadas pela Covid-19, a Baixada Fluminense, no Estado do Rio de Janeiro, que possui histórico de pobreza, violência e descaso do poder público. As iniciativas, que servem de exemplo para toda Igreja nestes tempos de pandemia, são inúmeras, e vão desde doações de respiradores a alimentos e somas em dinheiro. Isso revela um pastor que tem o desejo de um mundo baseado na cultura do amor e da solidariedade para que ninguém fique indiferente diante do sofrimento alheio e de que a Igreja esteja perto das pessoas, não só geograficamente, mas que compartilhe com elas a vida concreta. ${ }^{61}$

Na Igreja, a opção pelos pobres é uma tarefa de todos, "ninguém deveria dizer que se mantém longe dos pobres, porque as suas opções de vida implicam prestar mais atenção a outras incumbências", "ninguém pode sentir-se exonerado da preocupação pelos pobres e pela justiça social". ${ }^{62}$ Todos os batizados, incluindo os pastores, são chamados a preocupar-se com a construção de um mundo melhor, pois cada cristão e cada comunidade são chamados a ser instrumento de Deus a serviço da libertação e da promoção dos pobres, pois neles está presente o Crucificado. ${ }^{63}$

\section{Considerações finais}

A organização deste trabalho mostra que o Reino de Deus é a centralidade do anúncio de Jesus. Esse anúncio era a Boa Notícia de Deus, eu-aggelion, especialmente aos pobres, como nos evidenciam as bem-aventuranças; nelas, uma vez colocada de lado toda interpretação espiritualizante, fica clara a presença de um manifesto social. E o que faz os pobres serem os destinatários privilegiados deste reino é a situação de sofrimento, não as questões morais e religiosas, e também a misericórdia

\footnotetext{
61 VATICAN NEWS. Disponível em: http://www.vaticannews.va/pt.html. Acesso em: 7 ago. 2020.

62 EG, n. 201.

63 EG, n. 187.
} 
e compaixão de Deus na sua vontade de fazer de seu Reino um Reino de Justiça em favor dos desvalidos do mundo.

Respeitando os diferentes contextos histórico-sociais, a Igreja recebe a mesma missão de Jesus de Nazaré, ou seja, anunciar a Boa Nova do Reino de Deus. A instituição, por fidelidade ao seu mestre, deve também, na sua ação evangelizadora, privilegiar os pobres, pois só assim se tornará a "Igreja pobre para os pobres", como foi, comprometida com a transformação social como sonhara João XIII, no Concílio Vaticano II. E é nesse espírito que os bispos da América Latina assumiram, em Medellín, o compromisso solidário com pobres, que foi seguido por todas as outras Conferências. Mas a Igreja, na sua nota universal, volta à temática da pobreza, com olhar para o pobre, com a chegada de Francisco ao ministério petrino que, com a Exortação Apostólica Evangelii Gaudium, manifesta seu desejo ou sonho de uma Igreja mais samaritana e pobre para os pobres.

Na exortação, destaca a dimensão social da evangelização. Para Francisco, evangelizar é ser fiel a Jesus, ou seja, é tornar o Reino de Deus presente, especialmente aos pobres esquecidos por uma sociedade que os vê como descartáveis, pois é marcada pelo individualismo e pelo desejo de poder e dinheiro. Em sintonia com seu coração latino-americano, marcado por experiências de luta por justiça, insiste que a Igreja seja mediadora na construção de uma cultura da solidariedade, mas sabe que isso será resultado de um processo de conversão pessoal e comunitária. E conclama todos, sem exceção, a assumir sua responsabilidade e participação na mudança de estruturas eclesiais e religiosas, com o objetivo de a Igreja retomar sua fidelidade a Jesus de Nazaré, que foi pobre com os pobres. E, com isso, Francisco nos oferece uma chave hermenêutica para fazer teologia: "opção pelos pobres". Que nós - autores e leitor - tenhamos coragem de assumir esse compromisso de conversão e de hermenêutica. 


\section{Referências}

AQUINO JUNIOR, Francisco de. Uma Igreja pobre e para os pobres: abordagem teológico-pastoral. Revista Pistis \& Práxis, teologia e Pastoral. Curitiba, v. 8, n. 3, p. 631-757, set.-dez. 2016. Disponível em: http://periodicos.pucpr.br/index.phd/pitispraxis.com.br. Acesso em: 4 mar. 2020.

BARREIRO, Álvaro. Os pobres e o Reino: do evangelho a João Paulo II. São Paulo: Loyola, 1983.

BOAS, Alex; MARCHINI, Welder Lancieri. Medellín como recepção conciliar. In: SOUZA, Ney de; SBARDELOTTI, Emerson. Medellín: Memória, profetismo e esperança na América Latina. Petrópolis: Vozes, 2018. p. 110-121.

BOMBONATTO, Vera Ivanise. Jesus e a opção pelos pobres. In: OLIVEIRA, Pedro A. R. de (org.). Opção pelos pobres no século XXI. São Paulo: Paulinas, 2011. p. 139-156.

CABESTRERO, Teófilo. Primazia dos pobres na missão de Jesus e da Igreja. Influência do Concílio Vaticano II no magistério Episcopal de Medellín, Puebla e Santo Domingo. In: VIRGIL, José Maria (org.). Descer da cruz os pobres: Cristologia da libertação. Comissão teológica internacional. São Paulo: Paulinas, 2007. p. 49-57.

COSTA, Lourenço (org.). Documentos do Concílio Ecumênico Vaticano II. Trad. Tipografia Poliglota Vaticana. São Paulo: Paulus, 1997. (Col. Documentos da Igreja).

FERRARO, Benedito. Reino de Deus. In: Dicionário do Concílio Vaticano II. São Paulo: Paulus, 2015. p. 819-827.

GUTIÉRREZ, Gustavo. A força histórica dos pobres. Trad. Álvaro Cunha. Rio de Janeiro: Vozes, 1981.

LIBANIO, João B. A redescoberta do Reino na teologia. In: VIRGIL, José Maria (org.). Descer da cruz os pobres: Cristologia da libertação. Comissão teológica internacional. São Paulo: Paulinas, 2007. p. 189-198.

LOURENÇO, Vitor Hugo. A "opção preferencial pelos pobres" como chave hermenêutica da Exortação Apostólica Evangelii Gaudim. Revista de Cultura Teológica. São Paulo, ano XXV, n. 89, p. 380-407, jan.-jun. 2017. Disponível em: https://revistas.pucsp.br/culturateo/article/view/ rct.i89.31591/pdf. Acesso em: 11 maio 2020. 
MIRANDA, Mario França. A salvação de Jesus Cristo: A doutrina da graça. 2. ed. São Paulo: Loyola, 2009.

OLIVEIRA, Pedro A. Ribeiro de (org.). Opção pelos pobres no século XXI. São Paulo: Paulinas, 2011. (Col. Cidadania).

PASSOS, João Décio; SANCHES, Wagner Lopes (org.). Dicionário do Concílio Vaticano II. São Paulo: Paulinas, 2015.

PIÉ NINOT, Salvador. Introdução à Eclesiologia. Trad. João Peixoto Netto. São Paulo: Loyola, 1998.

SCHILLEBEECKX, Edward. História humana: Revelação de Deus. Trad. João Rezende Costa. São Paulo: Paulus, 1994. (Col. Teologia Sistemática).

SILVA, Rafael Rodrigues da. Pobreza Evangélica. In: Dicionário do Concílio Vaticano II. São Paulo: Paulus, 2015. p. 745-746.

SOUZA, Ney de. Pobreza da Igreja: História e teologia do documento 14 da Conferência de Medelín. Caminhos, Goiânia, v. 17, n. 2, maio-ago. 2019, p. 527-740. Disponível em: http://seer.pucgoias.edu.br/index.php/ caminhos/article/view/7196. Acesso em: 12 fev. 2020.

SOUZA, Ney de; SBARDELOTTI, Emerson(org.). Medellín: Memória, profetismo e esperança na América Latina. Petrópolis: Vozes, 2018.

VATICAN NEWS. Disponível em: http://www.vaticannews.va/pt.html. Acesso em: 7 ago. 2020.

VIRGIL, José Maria (org.). Descer da cruz os pobres: Cristologia da libertação. São Paulo: Paulinas, 2007.

\section{Documentos da Igreja}

A BÍBLIA de Jerusalém. São Paulo: Paulus, 2006.

CONSELHO Episcopal Latino Americano. Documento de Aparecida (DAp). Texto Conclusivo da V Conferência Geral do Episcopado Latino Americano e do Caribe. 7. ed. São Paulo: Paulus. 2008.

DOCUMENTOS do Concílio Ecumênico Vaticano II. Ad Gentes (AD). Trad. Tipografia Poliglota Vaticana. São Paulo: Paulus, 1997. (Col. Documentos da Igreja). 
DOCUMENTOS do Concílio Ecumênico Vaticano II. Lumen Gentium (LG). Trad. Tipografia Poliglota Vaticana. São Paulo: Paulus, 1997. (Col. Documentos da Igreja).

EVANGELIZAÇÃO no presente e no futuro da América Latina. Conclusões da Conferência de Puebla: texto oficial. (DP). 3. ed. São Paulo: Paulinas.

PAPA FRANCISCO. Evangelii Gaudium, a alegria do Evangelho: sobre o anúncio do Evangelho no mundo atual. (EG). São Paulo: Paulus, 2013. 